\title{
Exploring the Language Learning Needs across Different Levels: A Case for the Iranian Undergraduate and Postgraduate Genetics Students
}

\author{
Fatemeh Abbasian Boroujeni ${ }^{1}$ \& Saeed Ketabi ${ }^{1}$ \\ ${ }^{1}$ English Department, University of Isfahan, Isfahan, Iran \\ Correspondence: Fatemeh Abbasian Boroujeni, PhD student of Applied Linguistics, English Department, University \\ of Isfahan, Isfahan, Iran. Tel: 98-391-3126-7398. E-mail: abbasianf@gmail.com
}

Received: March 5, 2012 Accepted: April 18, 2012 Online Published: July 1, 2012

doi:10.5539/elt.v5n7p164 URL: http://dx.doi.org/10.5539/elt.v5n7p164

\begin{abstract}
The present research was conducted with the aim of examining the foreign language learning needs of graduate and postgraduate students of Genetics in Iran in order to help students to meet the growing present and emerging future language demands. The study was designed on a qualitative-quantitative survey basis using interviews and questionnaires which was administered to 35 undergraduate students, 18 postgraduate students, and 4 subject-specific instructors. To see whether the graduate and postgraduate students differed significantly in terms of their language needs, an independent sample t-test was used. Chi-square analysis was also conducted to examine the possible discrepancies across the perceived needs of the students and their parallel counterparts in the instructors' corpus. The findings of the study revealed some minor discrepancies with regard to the language needs and perceptions across different levels. The chi-square results also revealed very few differences between the students' and instructors' perceived needs.
\end{abstract}

Keywords: needs-analysis, academic learning needs, ESP, graduate and postgraduate students

\section{Introduction}

The significance of needs analysis (NA) in providing a reliable and valid basis for setting goals and objectives, developing syllabuses and teaching materials, as well as evaluation and renewal of the ESP (English for Specific Purposes) programs is highlighted in the present literature (Edwards, 2000; Richards, 2001; Kormos, et al, 2002; Flowerdew, 2005; Holme, and Chalauisaeng, 2006; Mazdayasna and Tahririan, 2008; to cite a few).

In learner-centered approaches, learner needs have been of prime importance and the study of these needs - known as needs analysis or needs assessment - has become an important part of curriculum design (Kormos et al., 2002). Hutchinson and Waters (1987) distinguish between two types of needs: target needs and learning needs. Target needs comprise necessities (what the learner has to know in order to function effectively in the target situation), lacks (the gap between target and existing proficiency of the learner), and wants (the learners' view on their needs). Learning needs, on the other hand, is a cover term for all the factors connected to the process of learning like attitude, motivation, awareness, personality, learning styles and strategies, social background. So, in needs analysis different stakeholders including: teachers, students and administrators in this process should be emphasized.

For designing any ESP courses needs analysis is an integral part for considering practical issues such as: syllabus design, materials development, and teaching and testing practices. However, due to the lack of implementing needs analysis, many ESP programs in their present condition do not seem to help the students acquire the kind of knowledge and skill they need to pursue their educational goals. For example, they are unable to utilize their knowledge of English in real-life situations to participate in international conferences or to communicate with foreign counterparts. In other words, despite the amount of time and energy spent, the learners fail to achieve the desired terminal behavior which is expected of them. Therefore, most of the ESP needs analysis research has primarily focused on identifying students' needs with respect to the four skills areas (reading, writing, listening, speaking) and it is logical to expect that the distribution of these needs will differ according to the point of view researched (e.g. students' or instructional staff's), level of study (undergraduate or graduate), and even area of specialization. Since textbooks play a very crucial role in the process of language teaching and learning, the evaluation of ESP materials is also very important in needs analysis. In other words, ESP material useful for one group may be a further barrier for another group of learners (Huang, et al. 2006).

In Iran ESP courses are only part of the undergraduate EFL programs and during postgraduate studies no ESP 
courses are offered to the students. The syllabi designers' assumption is that the ESP courses offered to undergraduate students can fulfill the student's present and future language needs which are mainly considered as improving reading comprehension. The comparison of the language needs of the undergraduate and postgraduate Genetics students can reveal the discrepancy between the needs across different levels. Discovering the gap between the present and target needs of students in different level can lead to devising more specialized ESP courses in academic reading, writing, and speaking. So, needs analysis should be the first step in any EFL teaching and learning context, by evaluating materials against students' characteristics and learning needs.

\section{Background}

Many researchers have conducted needs analysis projects worldwide. For instance, the following studies as a few examples have acknowledged the diversity of language learning needs. Holme and Chalauisaeng (2006) employed a qualitative technique to needs analysis, i.e., Participatory Appraisal (PA) to assess the evolvement of course structures as response to the changing needs. Instrumentation included transect walking, mapping, understanding daily schedule, brainstorming through semi-structured discussion, well-being ranking, cause and effect diagram, and matrix scoring of priorities. The students identified their problems as limited vocabulary, low ability in getting meaning of texts, lack of background knowledge, complicated sentences and negative attitudes about reading. They also suggested some solutions to these problems.

Biria and Tahririan (1994) investigated the efficacy of different methods of teaching ESP to see whether the communicative method is compatible with the goals of ESP teaching. They came to the conclusion that the teaching of ESP by a rhetorical approach is compatible with current ESP theories. Examining the language wants of English majors in Hungary, Kormos, et al., (2002) found that regardless of years of study, students use English mainly for academic purposes during their university studies. In order to provide a framework for understanding the learning of writing skills and publishing practices of nonnative English-speaking PhD students, Huang (2010) investigated the $\mathrm{PhD}$ students' perceptions of publishing and learning to write for publication. Findings showed that these students regard themselves as disadvantaged due to their limited proficiency in English.

Azizifar, et. al. (2010) carried out an evaluation of two series of ELT textbooks used for teaching English language in Iranian high schools from 1970 to the present. The results of the study revealed that ELT textbooks play the major role in students' achievement in English language in Iran when they provide enough opportunity for the learners to practice the language they are learning communicatively. Dehnad, et al. (2010) revised the present syllabi of ESP postgraduate courses on the basis of critical approach to needs analysis. A significant discrepancy was showed between what the students expressed as their needs and what the Ministry of Health actually prescribed as the syllabus.

Reviewing the related literature, the present study tries to provide a framework for understanding the language learning needs of students in different levels, by investigating their perceptions regarding language learning needs in all four skills (listening, speaking, reading, and writing) as well as different aspects of ESP courses such as, the objectives of the course and resources available in terms of materials and time constraint.

To gain a wider perspective regarding the students' language needs the instructors' views was also explored. Specifically, with the aim of understanding the present and future needs of the undergraduate and postgraduate Genetics students when devising syllabi, courses and materials a questionnaire was administered to provide answers for the following questions:

1. What are the most important perceived language learning needs of the Iranian Genetics students based on the undergraduate and postgraduate students' view as well as the instructors' attitude?

2. Are there any significant differences between the perceived needs of the undergraduate and postgraduate Genetics students?

3. Are there any significant differences between the students and instructors in their perception regarding the language learning needs?

\section{Method}

\subsection{Participants}

A total of 53 students, (35 undergraduate and 18 postgraduate) studying Genetics at Isfahan university as well as 4 subject-specific instructors who taught Genetics and ESP courses took part in this study. 13 of the postgraduate students were studying at Master's level and 5 of them were Ph.D. students. The age range of the participants was 21- 40, 32 females and 21 males. The participants had passed the ESP course and were mainly students in the last year of their university studies. There was no sample selection and all the participants were included in both phase 
of the study, i.e., interview and filling in the questionnaire.

\subsection{Instruments}

Instrumentation included a semi-structured interview and a questionnaire (designed for the students and the instructors). At the beginning of the study, interviews were conducted with all the undergraduate and postgraduate Genetic students and instructors. A list of issues emerged, such as: the language learning needs of the students, the respondents' attitudes towards available materials, time constraints, and the length of the course. Initially a modified version of Mazdayasna and Tahririan's (2008) questionnaire (Appendix A, section one) was adopted since the original questionnaire was very long and some parts were not related to the present study. The interview data provided input for adding some items mainly with regard to ESP material evaluation and developments (Appendix A, section two). The questionnaire consisted of 42 items, each of which used a six-point Likert scale ranging from 1 (Not at all) to 6 (To a very great extent).

\subsection{Procedures}

For the ease of comparison and statistical analyses the questionnaire was divided into different parts each of which was subsequently made of different sections.

The first section of the questionnaire aimed to explore the opinions of the undergraduate and postgraduate Genetics students on their expressed needs in using the four macro English skills for their studies. The second section was divided into two parts. The first part of the second section of the questionnaire aimed to mainly seek the Genetics students' attitudes concerning the evaluation of the present materials in developing different language skills, the assessment of the ESP content and the class size. The second part of the second section aimed to explore the opinions of the Genetics students concerning the development of new materials to address the growing demands of second language learning.

The filled in questionnaires were then computer-coded and analyzed. In the quantitative data analysis assuming a significance level of $0.05(\mathrm{p}<0.05)$, Statistical Package for the Social Sciences (SPSS) version 10 (SPSS Inc., 2001) was used for statistical operations needed for data analysis. The obtained data was analyzed using descriptive statistical procedures as well as t-tests. The independent sample t-test examined whether significant differences existed between the two groups of undergraduate and postgraduate subjects in terms of their perceptions regarding the language needs, and ESP materials. To test the hypothesis that there are differences among perceptions of undergraduate and postgraduate students and the ESP instructors concerning the language learning needs a Kruskal Wallis test was run to see whether statistically significant differences exists across the perceived needs of the students and their parallel counterparts in the instructors' corpus.

\section{Results and Discussion}

The results obtained for the two research questions posed in the study are presented in Tables 1-3. Table 1 shows the results obtained for the first question: What are the most important perceived language learning needs of the Iranian Genetics students based on the undergraduate and postgraduate students' view as well as the instructors? Since the data in this regard did not meet the requirements of parametric statistics, non-parametric techniques were used in estimating the rank means for the three groups. The obtained chi-square values revealed the significance of discrepancies between the parallel items across the corpora.

As shown in Table 1, the overall comparison of the ranked means across the three groups of undergraduate and postgraduate Genetics students as well as the Genetics instructors revealed no significant discrepancies in the respondents' views towards their perceived needs in the realms of both macro skills and material evaluation and development. 
Table 1. Chi-square test results and the mean ranks (M R) across the corpora for undergraduate (U) and postgraduate (P) students as well as the instructors (I)

\begin{tabular}{|c|c|c|c|c|c|c|c|c|}
\hline \multirow[b]{2}{*}{ Part } & & \multirow[b]{2}{*}{ Items \# } & \multicolumn{2}{|l|}{$\mathbf{U}$} & \multicolumn{2}{|c|}{$\mathbf{P}$} & & \\
\hline & & & M. R. & Asymp. Sig. & M. R. & Asymp. Sig. & M. R & Asymp. Sig. \\
\hline Part one & Listening & Q1 & 77.66 & 0.040 & 49.50 & .006 & 9.38 & .927 \\
\hline Macro & & Q2 & $\underline{103.5}$ & & $\underline{58.94}$ & & $\underline{12.25}$ & \\
\hline \multirow[t]{22}{*}{ Skills } & & Q3 & 87.86 & & $\underline{28.94}$ & & 11.25 & \\
\hline & & Q4 & 73.97 & & 49.61 & & 10.63 & \\
\hline & & Q5 & 96.99 & & 40.50 & & $\underline{9.00}$ & \\
\hline & Speaking & Q6 & 87.57 & .44 & 41.50 & .131 & $\underline{6.38}$ & .369 \\
\hline & & Q7 & 84.73 & & $\underline{35.72}$ & & $\underline{13.50}$ & \\
\hline & & Q8 & $\underline{75.64}$ & & 42.61 & & 10.50 & \\
\hline & & Q9 & 88.89 & & 53.06 & & 9.13 & \\
\hline & & Q10 & $\underline{111.19}$ & & $\underline{54.61}$ & & 13.00 & \\
\hline & Reading & Q11 & $\underline{108.37}$ & .003 & 51.17 & .082 & $\underline{12.75}$ & .583 \\
\hline & & Q12 & 95.37 & & $\underline{54.61}$ & & 10.13 & \\
\hline & & Q13 & 82.90 & & 40.28 & & 11.00 & \\
\hline & & Q14 & $\underline{65.99}$ & & $\underline{33.94}$ & & $\underline{6.75}$ & \\
\hline & & Q15 & 87.37 & & 47.50 & & 9.63 & \\
\hline & writing & Q16 & $\underline{75.34}$ & .068 & $\underline{26.28}$ & .000 & $\underline{9.13}$ & .778 \\
\hline & & Q17 & 90.03 & & $\underline{61.06}$ & & $\underline{15.75}$ & \\
\hline & & Q18 & 86.91 & & 41.28 & & 11.50 & \\
\hline & & Q19 & 82.89 & & 40.28 & & 13.88 & \\
\hline & & Q20 & $\underline{107.81}$ & & 58.61 & & 11.38 & \\
\hline & General & Q21 & $\underline{50.49}$ & .001 & 27.72 & .229 & $\underline{8.25}$ & .740 \\
\hline & skills & Q22 & $\underline{88.06}$ & & 37.17 & & 11.50 & \\
\hline & & Q23 & 70.86 & & $\underline{40.38}$ & & 13.50 & \\
\hline & & Q24 & 72.60 & & 37.28 & & $\underline{14.88}$ & \\
\hline Part two & Material & Q25 & $\underline{108.26}$ & .090 & 78.83 & .439 & 12.25 & .159 \\
\hline \multirow[t]{8}{*}{ Section one } & Evaluation & Q26 & 157.67 & & $\underline{84.83}$ & & 10.13 & \\
\hline & & Q27 & $\underline{165.59}$ & & 76.17 & & 12.25 & \\
\hline & & Q28 & 158.94 & & 68.50 & & 9.25 & \\
\hline & & Q29 & 164.14 & & 86.83 & & $\underline{6.75}$ & \\
\hline & & Q30 & 148.29 & & 89.50 & & 14.38 & \\
\hline & & Q31 & 160.43 & & 98.83 & & $\underline{14.89}$ & \\
\hline & & Q32 & 110.77 & & $\underline{64.50}$ & & $\underline{9.38}$ & \\
\hline & & Q33 & 143.06 & & 80.50 & & 13.48 & \\
\hline Part two & Material & Q34 & 160.89 & .076 & 93.83 & .009 & 23.25 & .371 \\
\hline \multirow[t]{8}{*}{ Section two } & development & Q35 & 173.21 & & $\underline{101.72}$ & & 26.25 & \\
\hline & & Q36 & 141.06 & & 73.83 & & 22.38 & \\
\hline & & Q37 & 138.26 & & 82.39 & & 25.50 & \\
\hline & & Q38 & $\underline{175.99}$ & & 68.13 & & 26.25 & \\
\hline & & Q39 & 161.87 & & 67.39 & & $\underline{27.13}$ & \\
\hline & & Q40 & 168.19 & & 99.61 & & 18.25 & \\
\hline & & Q41 & $\underline{128.94}$ & & 78.83 & & $\underline{15.50}$ & \\
\hline & & Q42 & 168.59 & & $\underline{57.39}$ & & 26.00 & \\
\hline
\end{tabular}

With regards to each section (Table 1) assuming a 0.05 level of significance, the chi-square values showed that the view of each group of respondents toward the items covered in each section is not consistent. For example, the chi-square values for the listening items were, $0.040, .006$, across the undergraduate and postgraduate students respectively, showing their diverse views regarding the items in this skill. However for other skills such as speaking $\left(X^{2}=.44\right.$ and $\left..131, \mathrm{p}<0.05\right)$ across the undergraduate and postgraduate students respectively, there was no discrepancies in the student's views regarding each item. The chi-square values for the instructors $\left(X^{2}=.927, .369, .583, .778, .740, .159\right.$, and $.371, \mathrm{p}<0.05$ for all the items. 
As illustrated in Table 2, a closer examination of the ranked means revealed consistency in the respondent attitudes towards the most and the least needed aspects in each section. As for the listening skill the highest means were 103, 58.94, and 12.25, related to the need for listening to lectures in the scientific conferences and the lowest means were $73.97,28.94$, and 9.00, related to listening in the news media and lessons across the undergraduate and postgraduate Genetics students as well as the Genetics instructors respectively.

Table 2. Differences in the perceived needs of undergraduate and postgraduate students

\begin{tabular}{|c|c|c|c|c|c|c|c|}
\hline \multirow[t]{2}{*}{ t } & \multicolumn{2}{|c|}{ Postgraduate } & \multicolumn{3}{|c|}{ Undergraduate } & \multirow[t]{2}{*}{ Macro Skills } & \multirow[t]{2}{*}{ Part } \\
\hline & SD & $\mathrm{M}$ & SD & $\mathrm{M}$ & Items \# & & \\
\hline-.038 & .970 & 4.67 & .802 & 4.66 & Q1 & Listening & Part one \\
\hline .348 & .970 & 5.00 & .781 & 5.09 & Q2 & & \\
\hline 3.614 & 1.295 & 3.56 & 1.087 & 4.77 & Q3 & & \\
\hline .557 & 1.199 & 4.56 & .815 & 4.57 & Q4 & & \\
\hline 3.386 & 1.132 & 4.11 & .767 & 5.00 & Q5 & & \\
\hline 2.675 & 1.617 & 3.44 & 1.322 & 4.41 & Q6 & Speaking & \\
\hline 0.01 & 1.64 & 3.11 & 1.477 & 4.29 & Q7 & & \\
\hline 1.388 & 1.46 & 3.56 & 1.348 & $\underline{4.11}$ & Q8 & & \\
\hline .837 & 1.43 & 4.22 & 1.067 & 4.51 & Q9 & & \\
\hline 2.372 & 1.665 & 4.22 & .822 & 5.03 & Q10 & & \\
\hline 2.046 & 1.283 & 5.00 & .657 & $\underline{5.54}$ & Q11 & Reading & \\
\hline .517 & .943 & 5.22 & .725 & 5.34 & Q12 & & \\
\hline 1.872 & 1.294 & 4.56 & .867 & 5.11 & Q13 & & \\
\hline 2.163 & 1.085 & 4.33 & .758 & 4.89 & Q14 & & \\
\hline 1.46 & 1.23 & 4.89 & .611 & 5.26 & Q15 & & \\
\hline 4.63 & 1.41 & 2.89 & 1.055 & 4.47 & Q16 & writing & \\
\hline .020 & .943 & 4.78 & 1.165 & 4.77 & Q17 & & \\
\hline 3.02 & .900 & 3.89 & 1.01 & 4.74 & Q18 & & \\
\hline 3.205 & 1.060 & 3.78 & .932 & 4.69 & Q19 & & \\
\hline 1.46 & 1.28 & 4.67 & 1.33 & 5.14 & Q20 & & \\
\hline .153 & .984 & 4.56 & 1.00 & 4.60 & Q21 & General & \\
\hline 2.213 & .840 & 5.00 & .781 & 5.51 & Q22 & skills & \\
\hline .076 & .619 & 5.13 & .845 & 5.14 & Q23 & & \\
\hline .937 & .689 & 5.00 & .759 & 5.20 & Q24 & & \\
\hline 2.44 & 1.76 & 2.67 & 1.11 & 3.63 & Q25 & Material & Part two \\
\hline .850 & 1.84 & 2.89 & 1.35 & 3.27 & Q26 & evaluation & Section one \\
\hline 1.84 & 1.68 & 2.56 & 1.36 & 3.35 & Q27 & & \\
\hline 2.08 & 1.74 & 2.33 & 1.48 & 3.29 & Q28 & & \\
\hline .821 & 1.87 & 3.00 & 1.37 & 3.37 & Q29 & & \\
\hline .310 & 1.68 & 3.00 & 1.66 & 3.15 & Q30 & & \\
\hline .250 & 1.35 & 3.22 & 1.40 & 3.32 & Q31 & & \\
\hline 1.56 & .840 & 2.00 & 1.33 & 2.54 & Q32 & & \\
\hline .129 & 2.00 & 3.00 & 1.27 & 3.06 & Q33 & & \\
\hline-2.60 & 1.32 & 5.11 & .88 & 4.30 & Q34 & Material & Part two \\
\hline-.49 & .705 & 5.44 & .59 & 5.35 & Q35 & Preparation & Section one \\
\hline .83 & 1.37 & 4.67 & .99 & 4.94 & Q36 & & \\
\hline 1.94 & .705 & 4.44 & .95 & 4.94 & Q37 & & \\
\hline 2.56 & .85 & 4.75 & .74 & 5.35 & Q38 & & \\
\hline 1.81 & .80 & 4.75 & .80 & 5.21 & Q39 & & \\
\hline-.26 & .97 & 5.33 & .82 & 5.26 & Q40 & & \\
\hline .88 & .84 & 5.00 & .77 & 5.21 & Q41 & & \\
\hline 1.21 & 1.28 & 5.00 & .81 & 5.35 & Q42 & & \\
\hline
\end{tabular}

The means in speaking skill were also compared. The highest means were $111.19,54.61$, and 13.50 related to the needs for this skill in speaking with the specialists in the real situation and in the conferences, and the lowest means 
were, $75.64,35.72$, and 6.38 related to participating in asking and answering questions in the classroom for the undergraduate and postgraduate Genetics students as well as the Genetics instructors respectively.

Regarding the ranked means in the reading skill, the highest means were, 108.37, 54.61, and 12.75, related to reading specialized paper- and the Internet-based texts and articles, the lowest means were, 65.99, 33.94, and 6.75, related to reading English newspapers and non-scientific journals, across the undergraduate and postgraduate Genetics students as well as the Genetics instructors respectively.

The comparison of means for the writing skills showed no significant discrepancies in the respondents' view regarding different items in this skill. The highest means were 107.8, 61. 06, and 15.75, related to writing scholarly articles, and the lowest means were $75.34,26.28$, and 9.13, related to taking notes while reading books or listening to lectures for the undergraduate and postgraduate Genetics students as well as the Genetics instructors respectively.

In the general study skills, the highest means were, $88.06,40.38$, and 14.88 related to learning Genetics expression and technical vocabularies, and the lowest means were 50.49, 27.72, and 8.25 for learning specialized conversation for undergraduate and postgraduate Genetics students as well as the Genetics instructors respectively.

While the comparison of the means across the parallel items in the second section concerning material evaluation and development revealed a few inconsistencies, it was almost congruent. For the first part of the second section, the highest means were $165.59,84.83$, and 14.98, related to the respondents' satisfaction of the ESP Genetics material in general, the emphasis on reading skill, and the evaluation of ESP content, and the lowest means were 108.26, 64.50, and 9.38, regarding the satisfaction of the ESP Genetics materials in improving writing skill and in the replacing specialized materials with other related materials across undergraduate and postgraduate Genetics students as well as the Genetics instructors respectively.

For the second part of the second section regarding the need for the development of new materials, the results displayed no significant discrepancies. The highest means were 175.99, 101.72, and 27.13, regarding the necessity of developing materials which covers the needs for scholarly article writing, considers the use of specialized resources through the internet, and emphasizes speaking skill. The lowest means were 128.94, 57.39, and 15.50, related to the needs to devise materials which include pictures, graphs and glossaries, across undergraduate and postgraduate Genetics students as well as the Genetics instructors respectively.

The results related to the second research questions: regarding the significant differences between the perceived needs of the undergraduate and postgraduate Genetics students, are summarized in Table 2. The undergraduate and postgraduate students' responses were examined in terms of the individuals' perceived needs in the two parts of the questionnaire across the two corpora. As Table 2 shows, considering level of significance $0.05, \mathrm{p}<0.05$, the means of undergraduate and the postgraduate students in part one ranged from a high of $5.54,(\mathrm{t}[51]=2.046)$ and $5.22(\mathrm{t}[51]=.517$ to a low of $4.11,(\mathrm{t}[51]=1.388$ and $2.89,(\mathrm{t}[51]=4.637)$ respectively. As for the part two, the means of undergraduate and the postgraduate students ranged from a high of $5.35,(\mathrm{t}[51]=2.56)$ and $5.44(\mathrm{t}[51]=.049$ to a low of 2.54, $(\mathrm{t}[51]=1.56)$ and 2.00, $(\mathrm{t}[51]=1.56)$ respectively. According to their needs perception statistically some difference in the overall means of the two groups was observed.

The observed differences however were more evident in the students view regarding the macro skills where discrepancies were observed in the following item, Q3, Q5, Q6, Q7, Q11, Q16, q18, and Q19. Regarding the students' perception in the second part only in a few items such as, Q25 related to material evaluation, and Q34 and Q38 related to material development, discrepancies were observed across two groups.

To explore the differences between the students' and instructors' perception regarding the language learning needs, in order to provide answer to the third research question a t-test was conducted. The results of the analysis comparing the means of the students' and instructors' view with regards to both macro skills and material development, summarized in Table 3, revealed no significant differences across the two corpora.

As Table 3 shows, considering level of significance $0.05, \mathrm{p}<0.05$, the means of the respondents in part one ranged from a high of 5.38, $(\mathrm{t}[55]=-.350)$ and $5.75(\mathrm{t}[55]=.817$ to a low of 3.93 , $(\mathrm{t}[55]=.795$ and $3.75,(\mathrm{t}[55]=.451)$ for the students and instructors respectively. As for the second part, the means of students ranged from a high of 5.38, ( $t$ $[55]=-.350)$ and $5.50(\mathrm{t}[55]=-1.018$ to a low of $4.59,(\mathrm{t}[55]=.151)$ and $4.50,(\mathrm{t}[55]=.151)$ for the students and instructors respectively. Based on the results displayed in Table 3 with regards to the comparison of the Sig. (2-tailed) value with $\mathrm{p}<.05$ no statistically significant differences in the means of the parallel items across the two groups' needs perception was observed. 
Table 3. Differences in the perceived needs of the Genetic students and instructors

\begin{tabular}{|c|c|c|c|c|c|c|c|c|}
\hline \multicolumn{4}{|c|}{ t $\quad$ instructors } & \multicolumn{2}{|c|}{ students } & \multirow[b]{2}{*}{ Items \# } & & \multirow[t]{2}{*}{ Part } \\
\hline Sig. (2 tailed) & t-value & SD & $\mathrm{M}$ & SD & $\mathrm{M}$ & & & \\
\hline-.443 & 1.83 & 1.031 & 3.75 & .117 & 4.66 & Q1 & Listening & Part one \\
\hline .212 & 1.26 & 5.00 & 4.50 & .116 & 5.06 & Q2 & & Macro Skills \\
\hline .831 & -.214 & 5.00 & 4.50 & .117 & 4.36 & Q3 & & \\
\hline .524 & .641 & .479 & 4.25 & .131 & 4.57 & Q4 & & \\
\hline .176 & 1.369 & .408 & 4.00 & .136 & 4.70 & Q5 & & \\
\hline .654 & .451 & .479 & 3.75 & .200 & 4.09 & Q6 & Speaking & \\
\hline .000 & -1.379 & .000 & 5.00 & .220 & 3.89 & Q7 & & \\
\hline .43 & -.795 & .645 & 4.50 & .190 & 3.93 & Q8 & & \\
\hline .790 & .268 & .475 & 4.25 & .165 & 4.42 & Q9 & & \\
\hline .700 & .388 & .577 & 5.00 & .168 & 4.75 & Q10 & & \\
\hline .417 & -.817 & .250 & 5.75 & .129 & 5.36 & Q11 & Reading & \\
\hline .902 & .124 & .479 & 5.25 & .110 & 5.30 & Q12 & & \\
\hline .517 & -.652 & .667 & 5.23 & .145 & 4.92 & Q13 & & \\
\hline .378 & .889 & .854 & 4.25 & .125 & 4.70 & Q14 & & \\
\hline .782 & .278 & .707 & 5.00 & .121 & 5.13 & Q15 & & \\
\hline .258 & -1.143 & .250 & 4.75 & .190 & 3.94 & Q16 & writing & \\
\hline .193 & -1.319 & .289 & 5.50 & .149 & 4.77 & Q17 & & \\
\hline .313 & -1.018 & .408 & 5.00 & .144 & 4.45 & Q18 & & \\
\hline .111 & -1.622 & .250 & 5.25 & .146 & 4.38 & Q19 & & \\
\hline .199 & -1.299 & .479 & 5.25 & .136 & 4.58 & Q20 & & \\
\hline .881 & .151 & .645 & 4.50 & .156 & 4.59 & Q34 & Material & Part two \\
\hline .725 & -.353 & .289 & 5.50 & .088 & 5.38 & Q35 & Preparation & $\begin{array}{l}\text { Section } \\
\text { two }\end{array}$ \\
\hline .488 & -1.698 & .250 & 5.25 & .156 & 4.85 & Q36 & & \\
\hline .967 & -.042 &. .250 & 4.75 & .125 & 4.77 & Q37 & & \\
\hline .422 & .813 & .285 & 5.50 & .116 & 5.16 & Q38 & & \\
\hline .313 & 1.018 & .500 & 5.50 & .115 & 5.06 & Q39 & & \\
\hline .252 & 1.157 & .629 & 4.75 & .121 & 5.29 & Q40 & & \\
\hline .346 & .951 & .250 & 4.75 & .110 & 5.13 & Q41 & & \\
\hline .972 & -.036 & .750 & 5.25 & .139 & 5.23 & $\mathrm{Q} 42$ & & \\
\hline
\end{tabular}

N students: 53, N Instructors: 4, Df: 55, P<.05

\section{Conclusion}

The assessment of students' learning needs is an indispensable first step in curriculum development and material preparation for academic or specific purposes. The present study was conducted to provide a profile of present and target undergraduate and postgraduate students' EFL needs. To this end, the assessment of perceptions of three major groups of stakeholders (i.e. undergraduate, postgraduate students, and content instructors was performed through triangulation of data. In line with Mazdayasna's and Tahririan's (2008) findings, the result of this study supported the view that the students need to increase their general proficiency. However, unlike the previous research in which the most frequently echoed skill was reading, the findings of the study with regards to the first research question revealed the emphasis of the undergraduate and postgraduate students on reading as well as on the speaking and writing skills. The subject specific instructors' view on the importance of the all four skills was also significantly consistent with the students. The status of English as an international language and as the dominant medium of international academic journals and the major language of the Internet has posed new language demands in terms of the focus on the four skills areas for both the undergraduate and postgraduate students.

While the need for the writing and speaking skills stems from the new requirements imposed on the students to be accepted in the higher levels or get graduated, the main problem lies on the fact that no provision is provided in meeting these needs. As Atai and Nazari (2011) argue, the current Iranian EAP courses are not designed systematically and coherently as they are not research-based. Normally, target needs are not operationally defined to the stakeholders at implementation level of the curriculum. Therefore, since significant improvements in the writing and speaking skill are considered important by all the respondents, it seems more logical to invest on these skills 
through remedial courses in which special emphasis is paid to writing scholarly articles and speaking in scientific contexts.

To provide answers for the second research question, the study explored the question of whether significant differences exist between the perceived needs of the graduate and postgraduate Genetics students. The results of the study revealed that all students greatly needed to increase their general proficiency by improving all four skills to a great extent. The postgraduates need to meet the variety of demands imposed by their level on them, such as; reading highly authentic papers and the Internet- based discipline-specific texts, and articles. They also need to listen to lectures in presentations and conferences and write scholarly articles which highlights the pressure of publishing in English. Speaking with native and non-native specialists in the conferences was also evident. However, for the undergraduates, the main aim of English classes has so far been helping students to improve their technical vocabulary, reading, and translation skills. The lack of significant discrepancies in the needs perception for macro skills across the two groups, showed that the needs for writing and speaking skill had emerged through the new requirements set for the students for the acceptance for master or $\mathrm{PhD}$ degrees, e.g., having published articles or presentation at conferences. Therefore, needs analysis should be viewed as an on-going process underlying course design and materials preparation in order to devise adequate specialized courses and subject-specific textbooks which suit students' needs in preparing them for the present as well their future needs.

The needs analysis of the Iranian graduate and postgraduate Genetic students demonstrated the multifaceted factors involved in determining the language needs of these students. The long term needs of the students to be part of the global scientific community were reflected in their need to write articles for the scientific journals, attend international conferences, and utilize a wide range of information via the Internet. The short term needs of the students were manifested in their desire to fulfill the academic requirements which was mainly reading subject specific materials. In sum, for needs portrayal to lead to realistic solutions, it should consider both the students' language learning needs as well as the deficiencies and constraints, i.e., resources available in terms of staff, materials, equipment, finances and time constraint, to provide guidelines for setting the necessary priorities.

\subsection{Implication of the Study}

The findings obtained from this needs analysis study may provide the basis for curriculum developers, syllabus designers, materials writers, methodologists, and evaluators. It can also raise the instructors' awareness regarding the ESP language learners' needs and preferences. The results of the study revealed the need for the development of highly specific ESP language syllabi, courses and materials in general and for the Genetic students in particular which addresses the language learners' immediate as well their long-term needs. The results also showed that the primary focus of the language learning needs analysis should be on identifying students' needs with respect to the four skills areas (reading, writing, listening, speaking), the point of view researched (e.g. students' or instructional staff's), level of study (undergraduate or graduate), and even area of specialization. For example, the high demands of postgraduate students for paper writing courses and materials highlights the pressure of publishing in English which needs to be met by devising appropriate courses and materials. Moreover, through these kind of studies students are encouraged to develop a critical awareness of their present and target needs and become more inclined to provide remedy for their language deficiencies.

\section{References}

Atai, M. R., \& Nazari, O. (2011). Exploring reading comprehension needs of Iranian EAP students of health information management (HIM): A triangulated approach. System, 39, 30-43. http://dx.doi.org/10.1016/j.system.2011.01.015

Azizifar, A., Koosha, M., \& Lotfi, A. R. (2010). An analytical evaluation of locally produced Iranian high school ELT textbooks from 1970 to the present. English Language Teaching, 3(4), 132-141.

Biria, R., \& Tahririan, M. H. (1994). The methodology factor in teaching ESP. English for Specific Purposes, 13(1), 93-101. http://dx.doi.org/10.1016/0889-4906(94)90027-2

Dehnad, A., Bagherzadeh, R., Bigdeli1, S., Hatami, K., \& Hosseini, F. (2010). Syllabus revision: a needs analysis Study. Procedia Social and Behavioral Sciences, 9, 1307-1312.

Edwards, N. (2000). Language for business: effective needs assessment, syllabus design and materials preparation in a practical ESP case study. English for Specific Purposes, 19, 291-296.

Flowerdew, L. (2005). Integrating traditional and critical approaches to syllabus design: the 'what', the 'how' and the 'why?' Journal of English for Academic Purposes, 4, 135-147. http://dx.doi.org/10.1016/j.jeap.2004.09.001

Holme, R., \& Chalauisaeng, B. (2006). The learner as needs analyst: The use of participatory appraisal in the EAP 
reading classroom. English for Specific Purposes, 25, 403-419. http://dx.doi.org/10.1016/j.esp.2006.01.003

Huang, S. C. (2006). Reading English for academic purposes - What situational factors may motivate learners to read? System, 34, 371-383.

Huang, J. C. (2010). Publishing and learning writing for publication in English: Perspectives of NNES PhD students in science. Journal of English for Academic Purposes, 9, 33-44.

Huang, J. C. et al. (2006). Pre-reading materials from subject matter texts-Learner choices and the underlying learner characteristics. Journal of English for Academic Purposes, 5, 193-206.

Hutchinson, T., \& Water, A. (1987). English for specific purposes-a learning-centered approach. Cambridge: Cambridge University Press.

Kormos, J. et al. (2002). Language wants of English majors in a non-native context. System, 30, 517-542. http://dx.doi.org/10.1016/S0346-251X(02)00045-3

Mazdayasna, G., \& Tahririan, M. H. (2008). Developing a profile of the ESP needs of Iranian students: The case of students of nursing and midwifery. Journal of English for Academic Purposes, 7, 277-289.

Richards, J. C. (2001). Curriculum development in language teaching. Cambridge: Cambridge University Press. http://dx.doi.org/10.1017/CBO9780511667220

SPSS, Inc. (2001). SPSS Version 10.0 [Computer software]. Chicago: SPSS Inc.

Appendix A. Students' Questionnaire

Dear Participants,

The following questionnaire is part of a research project that investigates the needs of medical sciences students taking English as a required course.

Background Information

1. Name and family name: (optional)

2. Age - years

A. Appendix A, Part one

The first section of the questionnaire aims to explore the opinions of the undergraduate and postgraduate Genetics students on their expressed needs in using the four macro English skills for their studies. Please tick (O) the relevant choice for each question.

Listening skills

\begin{tabular}{llllll}
\hline $\begin{array}{l}\text { To a } \\
\text { very } \\
\text { great } \\
\text { extent }\end{array}$ & $\begin{array}{l}\text { To a } \\
\text { great } \\
\text { extent }\end{array}$ & $\begin{array}{l}\text { To a } \\
\text { moderate } \\
\text { extent }\end{array}$ & $\begin{array}{l}\text { To } \\
\text { some } \\
\text { extent }\end{array}$ & $\begin{array}{l}\text { A } \\
\text { little }\end{array}$ & $\begin{array}{l}\text { Not at } \\
\text { all }\end{array}$
\end{tabular}

Speaking skills

\begin{tabular}{|c|c|c|c|c|c|c|}
\hline $\begin{array}{l}\text { To a very } \\
\text { great } \\
\text { extent }\end{array}$ & $\begin{array}{l}\text { To a great } \\
\text { extent }\end{array}$ & $\begin{array}{l}\text { To a moderate } \\
\text { extent }\end{array}$ & $\begin{array}{l}\text { To some } \\
\text { extent }\end{array}$ & A little & Not at all & $\begin{array}{l}\text { As a Genetics student, } \\
\text { I need English for: }\end{array}$ \\
\hline
\end{tabular}

6. participating in academic discussions

7.Speaking in class

8.asking and answering questions in class

9.asking and answering questions in seminars

10. talking with professionals in real situations 


\section{Reading skills}

\begin{tabular}{llllll}
\hline $\begin{array}{l}\text { To a very } \\
\text { great extent }\end{array}$ & $\begin{array}{l}\text { To } \\
\text { great } \\
\text { extent }\end{array}$ & $\begin{array}{l}\text { To } \\
\text { moderate } \\
\text { extent }\end{array}$ & $\begin{array}{l}\text { To some A little } \\
\text { extent }\end{array}$ & Not at all & $\begin{array}{l}\text { As a Genetics student, } \\
\text { I need English for: }\end{array}$ \\
\hline & & & $\begin{array}{l}\text {.11. reading specialized textbooks } \\
\text { 12. reading articles in professional journals } \\
\text { 13. reading posters and abstracts in conferences } \\
\end{array}$ \\
& & & $\begin{array}{l}\text { 14. reading English newspapers and magazines } \\
\text { 15. reading texts on the Internet }\end{array}$ \\
\end{tabular}

\section{Writing skills}

\begin{tabular}{llll}
\hline $\begin{array}{l}\text { To a very } \\
\text { great extent }\end{array}$ & $\begin{array}{l}\text { To a great } \\
\text { extent }\end{array}$ & $\begin{array}{l}\text { To a moderate } \\
\text { extent }\end{array}$ & $\begin{array}{l}\text { To some } \\
\text { extent }\end{array}$
\end{tabular}

General skills

\begin{tabular}{|c|c|c|c|c|c|c|}
\hline $\begin{array}{l}\text { To a very } \\
\text { great extent }\end{array}$ & $\begin{array}{l}\text { To a great } \\
\text { extent }\end{array}$ & $\begin{array}{l}\text { To a moderate } \\
\text { extent }\end{array}$ & $\begin{array}{l}\text { To some } \\
\text { extent }\end{array}$ & A little & Not at all & $\begin{array}{l}\text { As a Genetics student, } \\
\text { I need English for: }\end{array}$ \\
\hline & & & & & & $\begin{array}{l}\text { 21. learning specialized conversations } \\
\text { 22. learning the frequent Genetics } \\
\text { expression } \\
\text { 23. learning new words and expressions } \\
\text { 24. learning skimming and scanning } \\
\text { when reading }\end{array}$ \\
\hline
\end{tabular}




\section{B. Appendix A, Part two}

The first section of the second part aims to mainly explore the opinions of the Genetics students concerning their attitudes towards the evaluation of the present materials in developing different language skills. The students' opinion regarding the assessment of the ESP content and class size was also explored.

Materials evaluation

\begin{tabular}{|c|c|c|c|c|c|c|}
\hline $\begin{array}{l}\text { To a } \\
\text { very } \\
\text { great } \\
\text { extent }\end{array}$ & $\begin{array}{l}\text { To a } \\
\text { great } \\
\text { extent }\end{array}$ & $\begin{array}{l}\text { To a } \\
\text { moderate } \\
\text { extent }\end{array}$ & $\begin{array}{l}\text { To } \\
\text { some } \\
\text { extent }\end{array}$ & $\begin{array}{l}\text { A } \\
\text { little }\end{array}$ & $\begin{array}{l}\text { Not } \\
\text { at } \\
\text { all }\end{array}$ & As a Genetics student: \\
\hline & & & & & & $\begin{array}{l}\text { 25. I feel satisfied with the topics included in } \\
\text { the textbook } \\
\text { 26. I feel satisfied with my teacher's evaluation } \\
\text { method } \\
\text { 27. I feel satisfied with the present textbook } \\
\text { 28. I feel satisfied with the content of the } \\
\text { textbook } \\
\text { 29. I feel satisfied with teaching the related } \\
\text { textbooks in ESP classes } \\
\text { 30. I feel satisfied with the effect of the present } \\
\text { textbooks on my success in higher levels } \\
\text { 31. I feel satisfied with the effect of the present } \\
\text { textbooks on my reading skills } \\
\text { 32. I feel satisfied with the effect of the present } \\
\text { textbooks on my writing skills } \\
\text { 33. I feel satisfied with the number of students } \\
\text { in my class }\end{array}$ \\
\hline
\end{tabular}

The second section of the second part aims to explore the opinions of the Genetics students concerning the development of new materials to address the growing demands of second language learning.

Materials development

\begin{tabular}{lllllll}
\hline $\begin{array}{l}\text { To a very } \\
\text { great extent }\end{array}$ & $\begin{array}{l}\text { To } \\
\text { great } \\
\text { extent }\end{array}$ & $\begin{array}{l}\text { a } \\
\text { moderate } \\
\text { extent }\end{array}$ & a & $\begin{array}{l}\text { To some A little } \\
\text { extent }\end{array}$ & Not at all As a Genetics student: \\
\hline
\end{tabular}

34. it is necessary to develop new Genetics materials based on the students needs.

35. In devising new Genetics materials, it is necessary to use the Internet recourses.

36. In devising new Genetics materials, reading should be considered as the most important skill.

37. In devising new Genetics materials, writing skill should be considered.

38. In devising Genetics materials, the skill of writing scholarly articles should be considered

39. In devising Genetics materials, the skill of scholarly speaking should be considered.

40. In devising Genetics materials, improving the listening skill by attaching CDs should be considered.

41. In devising Genetics materials, pictures, graphs, tables and illustrations s should be considered.

42. In devising Genetics materials, specialized glossaries as well as references should be included. 